\title{
DO SOCIAL-ECONOMY VULNERABILITY INDEX AND POVERTY INDEX HAVE CORRELATION? STUDY IN BENGAWAN SOLO WATERSHED
}

\author{
Suryanto* \\ Universitas Sebelas Maret, Indonesia \\ Ratih Kumalasari \\ Universitas Sebelas Maret, Indonesia \\ Danur C. Guritno \\ Universitas Sebelas Maret, Indonesia \\ Nugroho Saputro \\ Center for Fintech and Banking, Universitas Sebelas Maret, Indonesia \\ Sabar Marniyati \\ Universitas Surakarta, Indonesia
}

\begin{abstract}
The components to measure of disaster risk (i.e flood) are level of hazard, vulnerability of individual/community, and capacity of individual/community. Research related to vulnerability is based on the level of probability of a region experiencing a disaster, while vulnerability is based on conditions where individual/community cannot cope with disasters. The aim of the study was to measure the level of vulnerability of the socio-economic and institutional society. This research tried to explain the level of social vulnerability among the communities in upper Bengawan Solo watershed. SoVI makes more appropriate parameters for measuring social vulnerability than relying only on partial socioeconomic data. The data generated from relevan institution, such as Central Bureau of Statistic (Badan Pusat StatistikBPS), Social Service Institution (Dinas Sosial), National Population and Family Planning Board. Data needed such as socio-economic community, demography, age, family structure, village-city, education, and unemployment rate. We find the data from the related agencies. The first step analysis is to adapt the measurement of vulnerability (SoVI) that has been developed. After the measurement of the SoVI is carried out then it is classified relatively between districts (Sragen, Sukoharjo, Wonogiri, and Karanganyar) in the upstream Bengawan Solo Watershed. The results show highest SoVI total score (the most vulnerability) is Sragen Regency, followed by Wonogiri and Sukoharjo, and the lowest is Karanganyar. Meanwhile, Sragen has the highest scores in social-economy components score such as age, gender, rural/urban, occupation, and family structure. It implies that when disasters attack to Sragen, their community will be more suffering potentially.
\end{abstract}

Keywords: Social Economy, Community, Vulnerability, Risk.

Received: 29 November 2020

Accepted: 10 May 2021

https://doi.org/10.33736/ijbs.3777.2021

\footnotetext{
- Corresponding author: Faculty of Economics and Business, Universitas Sebelas Maret, Jalan Ir.Sutami 36A Surakarta; Email: suryanto_feb@staff.uns.ac.id
} 


\section{INTRODUCTION}

Disaster is a phenomenon that occurs as a result of the impact of hazards and vulnerabilities simultaneously that can affect environmental conditions or areas in managing threats (Oxfam, 2012 in Hapsoro \& Buchori, 2015). Floods that occur every year in several districts or regencies that pass through the river cause socio-economic vulnerability in these districts or regencies.

Societies that have a high dependency on natural resources are very vulnerable to changes in rainfall (Boissiere et al., 2013); Lintner et al., 2012 in Auliyani \& Wahyuningrum, 2020). Societies in Java island especially some parts of regencies in Bengawan Solo Watershed are often experienced by floods. According to National Board for Disaster Management (BNPB) in 2015, Java Island is the most frequently exposed by the flood. Societies in Java Island suffered physical losses of up to USD 4,502 million and drought with a loss of up to USD 3,899 million (Amri et al., 2016).

The Bengawan Solo is one of the largest watershed and longest river flow on the island of Java, Indonesia. This river has a length of $548.53 \mathrm{~km}$ with a watershed area of $16,100 \mathrm{~km}^{2}$ and crosses two provinces, namely Central Java and East Java. Its area covering $\pm 12 \%$ of the entire island of Java. Bengawan Solo has a problem of drought and seawater intrusion during the rainy season in several areas where floods often occur and vice versa in the dry season which results in considerable loss of property and human life (Auliyani \& Wahyuningrum, 2020). Therefore, studies on vulnerability in the Bengawan Solo watershed are needed to prevent greater material and non-material losses related to natural disasters.

According to Rusminah \& Gravitian (2012) Central Java has seven regencies/municipalities that are passed by the Bengawan Solo River. Among the seven regencies/municipalities, Surakarta is an area that does not have large agricultural land. Surakarta as a municipality has a small contribution from agricultural sector. Surakarta has farmland for rice production area only 36 hectares and produces 230 tons per year (2018). Meanwhile, other areas such as in Wonogiri, Regency, Sukoharjo Regency, Karanganyar Regency, and Sragen Regency have broader agricultural land areas. The impact of climate change, especially flooding in the agricultural sector, triggers the increased social vulnerability. In this research, the areas to be studied are Wonogiri, Sukoharjo, Karanganyar, and Sragen regencies.

Climate change has been believed as one of the factors that causing the flood in several areas. Climate change is the change in climate variables, especially air temperature and rain intensity that occur gradually around 50 to 100 years (Runtunuwu \& Syahbuddin, 2007); (Hettiarachchi, et al., 2018). When the disaster struck to society, there will be many aspects that get hampered such as the socio-economic aspect. Areas that frequently faced natural disasters such as floods usually have to bear the negative impacts in socio-economic life than other areas. The disruption in the social-economy condition in an area can increase the vulnerability of the area.

One of the most affected groups is the agriculture sector. For farmers, the land is an earning asset that can generate revenue (Surmaini et al., 2015; Suryanto et al., 2017). Therefore, when their farmland is flooded, they cannot cultivate their crops which reduces their revenue. There is a correlation between the population's vulnerability to poverty and their residence ecosystem, thus the level of poverty will differ from each agro-ecosystem (Ali \& Erenstein, 2017). The 
vulnerable society will harder to cover their basic needs compared to the less vulnerable society. However, the vulnerability can also be caused by the socioeconomic conditions of the community. One of the factors causing vulnerability is poverty. People who are in poor condition will tend to be vulnerable. This means that the factors of vulnerability and poverty are thought to have a positive relationship.

Measurement of social vulnerability has been carried out using several approaches, for example, the Social Vulnerability Index, the Livelihood Vulnerability Index, or the Climate Disaster Resilience Index. All measurement models rely on relative comparisons between regions in a single study. Meanwhile, the poverty indicators show individual conditions and do not show collective conditions. This study aims to find out whether the vulnerability has a relationship with the poverty index. If poverty has a relationship with vulnerability, then SoVI in the Bengawan Solo watershed can be predicted from the poverty level. In this research we collect data from Bengawan Solo watershed covers for the regency of Wonogiri, Sukoharjo, Karanganyar, and Sragen.

\section{LITERATURE REVIEW}

Disaster Risk Management (DRM) could not be success without concern to improve the capability of society. DRM will need to address not only the physical aspect, but also the economic and social factors which influence the greater society and reinforce the impact of hazardous events (Mcentire, 2012). A better preparation and precisely calculation of risk is an important and long overdue addition to the hazard mitigation planning and implementation processes (Opiyo et al., 2015; Iglesias et al., 2011) especially in the context of climate change adaptation and disaster risk reduction strategies.

Social vulnerability is measured using various method in the previous researches. SoVI has introduced by Shirley et al. (2003), they developed SoVI to identify and mapping the level social vulnerability in Mississippi Delta Region. This model has been adapted and adjusted depend on local characteristics aspects. Research by Lawal and Arokoyu, (2015) and use the Social Vulnerability Index method in measuring the vulnerability.

Vulnerability can be defined as a weakness to anticipate the potential for something that has a risk. Lawal and Arokoyu (2015) stated that vulnerability is a loss of life or properties as the result of a natural disaster. Furthermore, according to Miyan (2015) and Lawal and Arokoyu (2015), vulnerability consists of two categories, namely biophysical and social vulnerability. Biophysical vulnerability can cause food insecurity, drought, flood, bad weather, etc, meanwhile social vulnerability leads them to suffer from disease, loss of property, etc. They conducted research to measure social vulnerability in Sub-Sahara area especially West Africa. They found that the impact of disasters tends to be more devastating in developing countries as a result of the interaction between population growth, land pressure, economic growth, technological innovation, social expectations, and growing interdependence. They also resulted the differentiation of the social vulnerability score among Local Government Areas (LGA) by Social Vulnerability Index.

Implementation of the index of social vulnerability (SoVI) has been conducted by Lawal and Arokoyu (2015). They used a sample of Nigeria's Southwest Zone, which consists of six states, 
namely Ekiti, Lagos, Ogun, Ondo, Osun and Oyo and this region has 137 local government areas (LGA). The result indicates that Ondo and Ekiti have LGAs are more vulnerable than other countries in the region. While research by Shirley et al. (2003) establish several spatial patterns in SoVI calculation, in which the most vulnerable regency located in East Metropolitan area, South Texas, and Mississippi Delta area. Another research conducted by Setyaningrum and Giyarsih (2012) found that the vulnerability level of the community that resides around Kali Code Riverbank is low and more affected by the economic factor. They conclude that social and economic vulnerability with people perception have negative correlation. It will impact to high loss potential toward societies.

Meanwhile, Suryanto (2017) supported the finding from (Setyaningrum \& Giyarsih, 2012), in his research tried to evaluate the negative impact of flood in Surakarta city. He stated a vulnerable area to the natural disaster is often socially vulnerable more compared to the areas that less prone to natural disasters. Research from Widiarto and Kingma (2014) also reported that impact of vulnerability to flood can disrupt the development and economic growth in Sragen.

Another research on vulnerability is conducted by Shah et al. (2013), which analyze farmers' vulnerability toward climate change. The method used is different from SoVI score calculation, they tried to estimate with another approach. They used the Livelihood Vulnerability Index (LVI) method. Razafindrabe et al. (2009) in contrast, examined the resilience of a region toward disasters that occur as an effect of climate change on the Asian coastal area. The method was the Climate Disaster Resilience Index (CDRI). Research conducted by Shah et al. (2013) found that Narvia is more vulnerable than Caroni, especially in socio-demographics, health condition and water availability, natural disaster, and climate variability. Razafindrabe et al. (2009) suggest that the type of vulnerability in each area varies. Thus, a policy that recommend to be conducted for the area will be different.

Almost all SoVI or LVI measurements method rely on secondary data, which is then compared among regions. This measurement relies on relative sizes and contains weaknesses if several areas used have almost the same level of vulnerability.

\section{METHODOLOGY}

Bengawan Solo Watershed through 17 regencies/municipalities in two provinces, Central Java and East Java. There two steps to analysis the data, first step is calculation of social vulnerability index and second step is Geographical Information System. In SoVI approach we describe the socio-economic living, the level of social vulnerability, the comparison mapping of social vulnerability as a basis of consideration for the development policy of Bengawan Solo watershed area. The Social Vulnerability Index (SoVI) has been developing to measure the vulnerability level in each regency. After the SoVI score is obtained, a Geographical Information System conducted to describe the most vulnerable regency.

The research took place on the areas located around Bengawan Solo watershed with the developed agricultural sector. Therefore, the four regencies which located in Bengawan Solo River watershed are chosen for this study namely: Wonogiri, Sukoharjo, Karanganyar, and 
Sragen. Four regencies have known as main supplier for rice to Java island people, especially in Central Java Province.

SoVI approach relied on secondary data, that has been generated from other institutions or organizations related to this study. This data will be used to examine the social vulnerability level of the society in Bengawan Solo River watershed area. The secondary data are obtained from the Central Bureau of Statistic (Badan Pusat Statistik-BPS), Social Service Office (Dinas SocialDinSos), One-door Integrated Investment and Licensing Offices (Dinas Penanaman Modal dan Perijinan Terpadu Satu Pintu-DPMPTSP), Population and Family Planning Bureau (Badan Kependudukan dan Keluarga Berencana Nasional), General Election Commission (Komisi Pemilihan Umum-KPU), and Financial and Regional Assets Management Office (Dinas Pengelolaan Pendapatan Keuangan dan Aset-DPPKA), which located in the Regency of Wonogiri, Sukoharjo, Karanganyar, and Sragen.

The SoVI score for each regency calculated using Microsoft Excel and SPSS 16 based on estimating for each regency. The results discussed descriptively to get socio-economic conditions for each regency. GIS method used to figure out the level of vulnerability among four regencies. By the GIS approach, it makes easier for us to analyse data on vulnerability.

Social Vulnerability Index (SoVI) Analysis: a method that will generate the social vulnerability score for each area in this research. Therefore, in order to provide the score that will be used in the SoVI calculation, the z-score of each sub-component should be computed previously, Z-score is needed because the size and data units used in the analysis are different. The socioeconomic measurement differs from the measurement for age and property. The Z-score accommodates the different unit measurements into comparable unit among regions. The Z-score calculated using the following formula:

$$
z=\frac{x-\mu}{\sigma}
$$

Note:

$\mathrm{z}=\mathrm{z}$-score

$\mathrm{x}=$ base value

$\mu=$ the average value

$\sigma=$ standard deviation

After the z-score is computed, which mean the standard value for each sub-component is obtained, a varimax rotation method is used to know the correlation between a sub-components with another sub-component. The aim of varimax rotation is to test whether the factor score of each component is overlapping with other components. Based on the Rotated Component Matrix in the varimax rotation output, if there is more than one component that has a score above 0.50 then the component is overlapping with other components, thus the component should be eliminated.

After the overlapping components are eliminated, the next step is to decide whether the remaining components represent more than 50 percent of the total components before elimination. 
If the remaining component represents more than 50 percent than the total component, the SoVI score computation can be continued.

The remaining components that represent the total component are scored. The scoring is conducted by categorizing the z-score into the classes or groups that have had prepared. The groups is calculated based on Sturgess Formula and it is needed to determine how many groups of vulnerabilities can be created based on the data. The classification of vulnerable groups is determined in a range based on the calculation results. For example, the category is vulnerable if the SoVi score is above 70. The class determination of the Sturgess model can be determined based on a formula,

Number of Class $=1+3.3 \log n$, with $n$, is the number of $n$ data

Range $=$ highest score - the lowest score

Class length $=$ Range $/ \mathrm{K}$

After the class has prepared, the z-score of each component is classified into the class. Moreover, each sub-component is analyzed whether it increases or decreases the vulnerability. The next step is by adding up all the sub-components, which represent the SoVI score. This score will be used to prepare the vulnerability map. The area with the highest SoVI score is the area with the highest level of social vulnerability, vice versa. The classification of vulnerability level is based on the class. In this research, the classification is divided into three classes, namely, low, medium, and high vulnerability. The classification of vulnerability classes use a relative scale; the same method used for the scoring of level vulnerability.

The explanation of social vulnerability indicators refers to Shirley et al. (2003), (Kusenbach et al., 2010), Lee (2014), and McEntire (2012) of social-economic status are used to describe the level of a region's macroeconomy. The number of votes in the presidential election illustrates the awareness of the economic preference of candidates. The higher the regional domestic regional gross, the higher the capacity of an area to overcome the risk of flooding.

Age indicator shows the age composition of the population of an area. If more and more of the population is elderly, it shows that the population is more vulnerable. With almost the same explanation, it also occurs in the health indicator. The higher the number of doctors in an area, the lower the level of vulnerability faced.

The property indicator shows the level of dependence of the GDRP on the agricultural sector. If the contribution of the agricultural sector is high, the regency will have a high dependence on the agricultural sector. Meanwhile the agricultural sector is very dependent on the climate. Conversely, the region has a low vulnerability if the dependence on the agricultural sector is low.

The other SoVI indicators are sex, demography, and social dependence. Sex is an indicator that shows the proportion of the sex of the population. Meanwhile, demography reflects the level of population density and social dependence shows the proportion of the population who has participated in the BPJS insurance program. The proportion of the population that is dominated by women is considered to have a higher vulnerability. Meanwhile, a high level of population density is considered to have a higher level of vulnerability. 
Table 1. The Indicator and Sub-indicator of Social Vulnerability Index (SoVI)

\begin{tabular}{|c|c|c|}
\hline Indicator & Sub-indicator & Sub-indicator explanation \\
\hline \multirow[t]{5}{*}{$\begin{array}{l}\text { Social- } \\
\text { economy status }\end{array}$} & $\begin{array}{l}\text { Percapita income } \\
\text { The dependency ratio of government to } \\
\text { general allocation fund. }\end{array}$ & $\begin{array}{l}\text { The income earned by e person in a } \\
\text { spesific year. } \\
\text { The Amount of General Allocation } \\
\text { Funds in Regency/City income balance } \\
\text { funds }\end{array}$ \\
\hline & $\begin{array}{l}\text { The number of votes in the presidential } \\
\text { election }\end{array}$ & $\begin{array}{l}\text { The number of voters who voted in the } \\
2014 \text { presidential election }\end{array}$ \\
\hline & The percentage of family welfare & $\begin{array}{l}\text { The number of household having more } \\
\text { total income than regional minimum } \\
\text { wage. }\end{array}$ \\
\hline & $\begin{array}{l}\text { The percentage of people live under } \\
\text { poverty line }\end{array}$ & The number of poor people \\
\hline & $\begin{array}{l}\text { The number of households that own } \\
\text { car }\end{array}$ & The number of households that own car \\
\hline \multirow[t]{3}{*}{ Age } & Average age & $\begin{array}{l}\text { The average age of population in a } \\
\text { regency/city }\end{array}$ \\
\hline & The number of elderly & $\begin{array}{l}\text { The number of population over } 65 \text { years } \\
\text { old }\end{array}$ \\
\hline & The number of toddler & The number of children under 5 years old \\
\hline \multirow[t]{5}{*}{ Property } & The rental cost of occupied housing & $\begin{array}{l}\text { Average rental cost housing paid by } \\
\text { community }\end{array}$ \\
\hline & The number of Building Permit (IMB) & $\begin{array}{l}\text { The number of building permit that } \\
\text { issued by government }\end{array}$ \\
\hline & The number of companies & The number of companies in regency/city \\
\hline & Company productivity & $\begin{array}{l}\text { The average value of company } \\
\text { productivity }\end{array}$ \\
\hline & GRDP Agriculture & $\begin{array}{l}\text { Agricultural sector contribution to } \\
\text { Regency / City income }\end{array}$ \\
\hline \multirow[t]{3}{*}{ Health } & The number of doctors & $\begin{array}{l}\text { The number of doctors, nurse, and } \\
\text { midwife. }\end{array}$ \\
\hline & $\begin{array}{l}\text { The number of people living in nursing } \\
\text { homes. }\end{array}$ & $\begin{array}{l}\text { The number of people living in nursing } \\
\text { homes. }\end{array}$ \\
\hline & The number of health facilities. & $\begin{array}{l}\text { The number of health facilities such as } \\
\text { hospital and health center. }\end{array}$ \\
\hline \multirow[t]{3}{*}{ Demography } & The percentage of population change & $\begin{array}{l}\text { The comparison of population changes } \\
\text { from the previous year }\end{array}$ \\
\hline & Birth rate & $\begin{array}{l}\text { Number of births in a Regency / City in } 1 \\
\text { year }\end{array}$ \\
\hline & Population density & $\begin{array}{l}\text { The average of population density in } \\
\text { district/ city. }\end{array}$ \\
\hline Education & The number of high school graduate & $\begin{array}{l}\text { The number of residents who have a high } \\
\text { school certificate }\end{array}$ \\
\hline \multirow{5}{*}{$\begin{array}{l}\text { Sex } \\
\text { Unemployment } \\
\text { Rural/urban } \\
\text { area }\end{array}$} & The number of female & The number of female citizenship \\
\hline & The number of unemployment & The number of unemployed workforce \\
\hline & Land used by farmers & The amount of land used for agriculture \\
\hline & The number of farmers & $\begin{array}{l}\text { The number of residents who work as } \\
\text { farmers }\end{array}$ \\
\hline & The population of urban area & The number of residents living in urban \\
\hline
\end{tabular}




\begin{tabular}{|c|c|c|}
\hline Indicator & Sub-indicator & Sub-indicator explanation \\
\hline $\begin{array}{l}\text { Social- } \\
\text { economy status }\end{array}$ & $\begin{array}{l}\text { Percapita income } \\
\text { The dependency ratio of government to } \\
\text { general allocation fund. }\end{array}$ & $\begin{array}{l}\text { The income earned by e person in a } \\
\text { spesific year. } \\
\text { The Amount of General Allocation } \\
\text { Funds in Regency/City income balance } \\
\text { funds } \\
\text { areas }\end{array}$ \\
\hline $\begin{array}{l}\text { Social } \\
\text { dependence }\end{array}$ & $\begin{array}{l}\text { Social dependence Number of BPJS } \\
\text { Health users }\end{array}$ & $\begin{array}{l}\text { Number of residents using BPJS Health } \\
\text { facilities }\end{array}$ \\
\hline $\begin{array}{l}\text { Number of } \\
\text { people with } \\
\text { special needs }\end{array}$ & $\begin{array}{l}\text { The number of people who have } \\
\text { physical, and mental limitations }\end{array}$ & \\
\hline Renter & & The percentage of renter \\
\hline \multirow[t]{5}{*}{ Job } & $\begin{array}{l}\text { Working workforce } \\
\text { The number of working female }\end{array}$ & $\begin{array}{l}\text { The number of workforce employed } \\
\text { The number of female work force } \\
\text { employed }\end{array}$ \\
\hline & $\begin{array}{l}\text { The number of worker in agriculture, } \\
\text { fishery, and forestry (primary industry) }\end{array}$ & $\begin{array}{l}\text { The number of people whose livelihoods } \\
\text { work in the agriculture, fisheries, mining } \\
\text { and forestry sectors }\end{array}$ \\
\hline & $\begin{array}{l}\text { The number of residents working in the } \\
\text { transportation, communication and } \\
\text { other public facilities sectors }\end{array}$ & $\begin{array}{l}\text { The number of residents working in the } \\
\text { transportation, communication and other } \\
\text { public facilities sectors }\end{array}$ \\
\hline & $\begin{array}{l}\text { Number of people working in the } \\
\text { public service sector (services) }\end{array}$ & $\begin{array}{l}\text { Number of residents whose livelihoods } \\
\text { work in the public service sector } \\
\text { (services) }\end{array}$ \\
\hline & $\begin{array}{l}\text { The number of Indonesian Migrant } \\
\text { Workers (TKI) }\end{array}$ & $\begin{array}{l}\text { The number of Indonesian Migrant } \\
\text { Workers (TKI) }\end{array}$ \\
\hline \multirow{2}{*}{$\begin{array}{l}\text { Family } \\
\text { structure }\end{array}$} & The average number of family member & The average member in one family. \\
\hline & Women as head of the family & $\begin{array}{l}\text { Population of women who act as heads of } \\
\text { families (do not have husbands) }\end{array}$ \\
\hline
\end{tabular}

Source: modified from Shirley et al. (2003)

Socio-Economics Description: this analysis is conducted to describe the socio-economic condition of the communities that reside in the Bengawan Solo River watershed area. The socioeconomic description is conducted using descriptive statistic method. The data used in this analysis is the result of z-score in the SoVI assessment. Each main component will be used to compare the vulnerability in each area, which will simplify the description of the socio-economic condition.

The Analysis Using Geographical Information System (GIS): GIS will be conducted to describe the most vulnerable regency among the four regency, based on the SoVI score.

This part explains how the research is conducted, research deGISn, data collecting techniques, instrument development, and data analysis techniques. 
Table 2. Summary of Research Method

Research Objective $\quad$ Analysis Tools Data Result

\begin{tabular}{llll}
\hline $\begin{array}{l}\text { Social Vulnerability of the } \\
\text { community that live at Bengawan } \\
\text { Solo River watershed area }\end{array}$ & $\begin{array}{l}\text { Social } \\
\text { Vulnerability } \\
\text { Index (SoVI) }\end{array}$ & $\begin{array}{l}\text { Secondary } \\
\text { Data }\end{array}$ & $\begin{array}{l}\text { Social Vulnerability } \\
\text { Index }\end{array}$ \\
$\begin{array}{l}\text { Mapping of the most vulnerable } \\
\text { area at the Bengawan Solo River } \\
\text { watershed areas }\end{array}$ & $\begin{array}{l}\text { Geographical } \\
\text { Information } \\
\text { System (GIS) }\end{array}$ & $\begin{array}{l}\text { Secondary } \\
\text { Data }\end{array}$ & $\begin{array}{l}\text { Social Vulnerability } \\
\text { Map }\end{array}$ \\
\hline
\end{tabular}

Source: research method (2017)

\section{RESULT AND DISCUSSION}

\subsection{Social-Economic Description}

This analysis is performed to understand the social-economy life in Bengawan Solo watershed. Descriptive statistic is utilized to explain the social-economy description. The data employed are from z-score calculation in the process of SoVI scoring. Each main component will be explained the comparison in each area. Thus, it will be able to see the description of social-economy indicators (see on Table 1). Some figures below represent each component of SoVI variable.

Figure 1. Dependence of Transfer Allocation Fund (DAU)

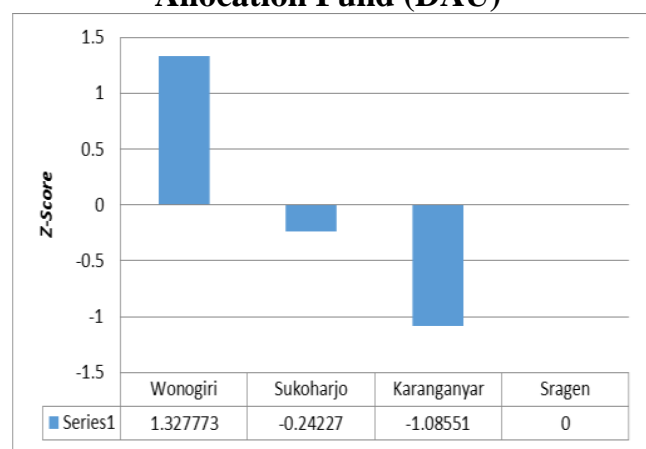

Source: Central Bureau of Statistics
Figure 2. The Number of Citizens Older than 65 Years

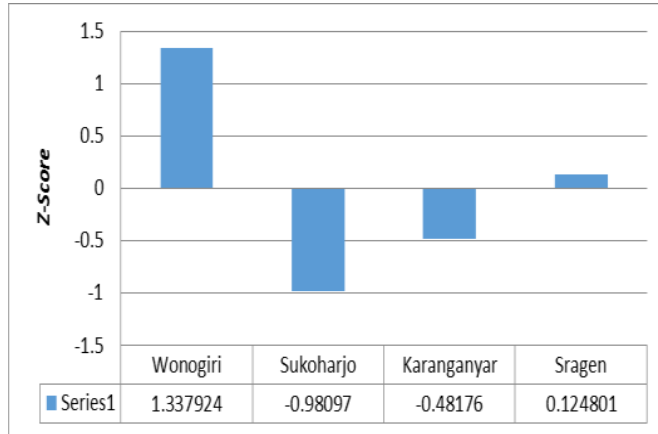

Source: Central Bureau of Statistics 
Figure 3. The number of Firms

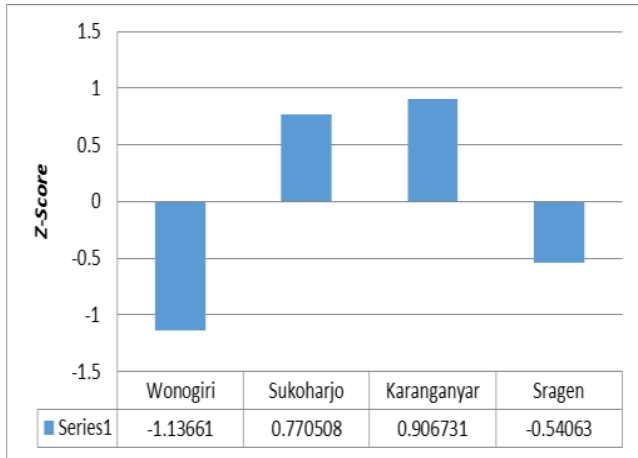

Source: Central Bureau of Statistics

\section{Figure 5. Birth Rate}

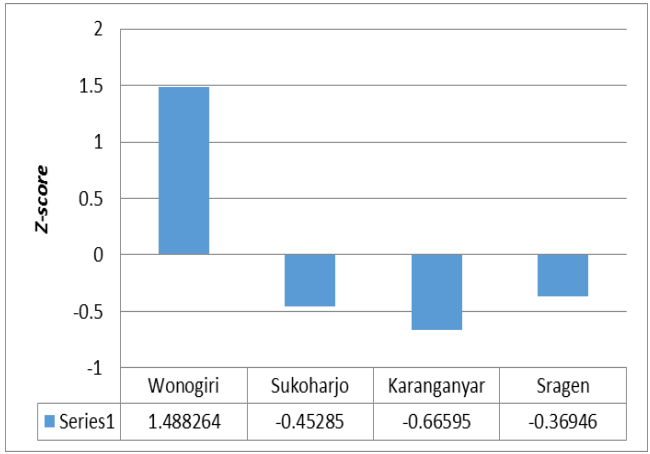

Source: Central Bureau of Statistics

Figure 7. The Number of Farmers in Rural

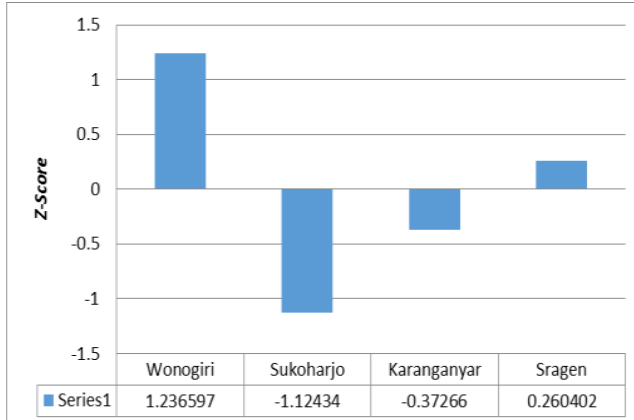

Source: Central Bureau of Statistics
Figure 4. The number of people living in nursing homes

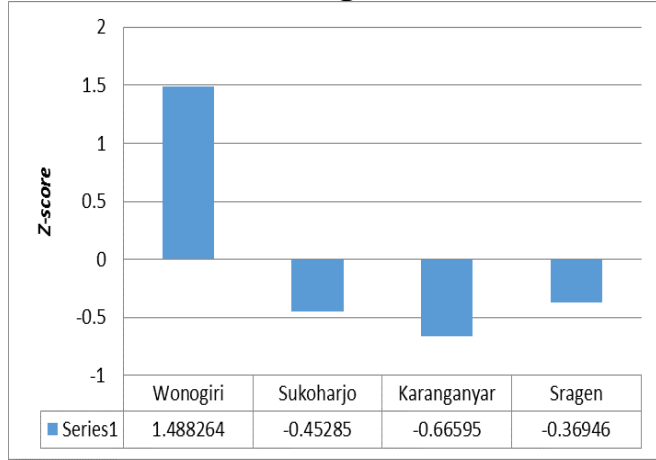

Source: Central Bureau of Statistics

Figure 6. Proportion of Citizens Living in Rural/Urban

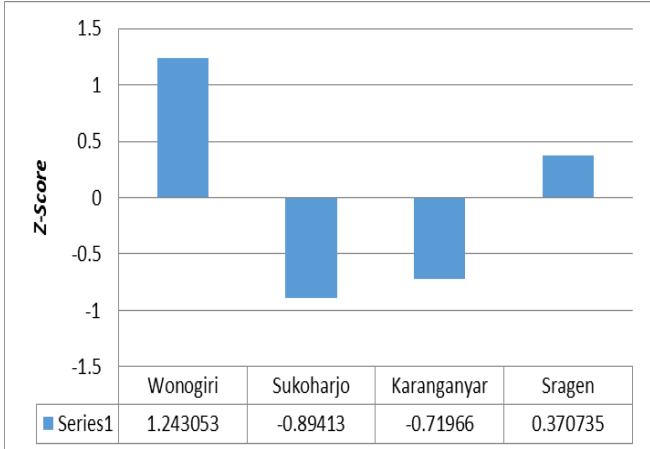

Source: Central Bureau of Statistics

Figure 8. Percentage of Women

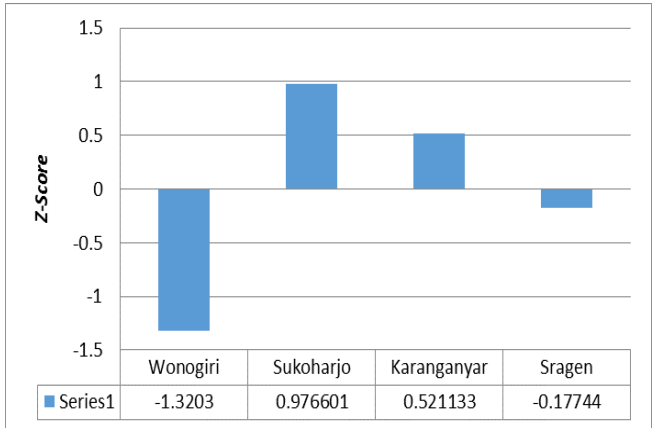

Source: Central Bureau of Statistics 


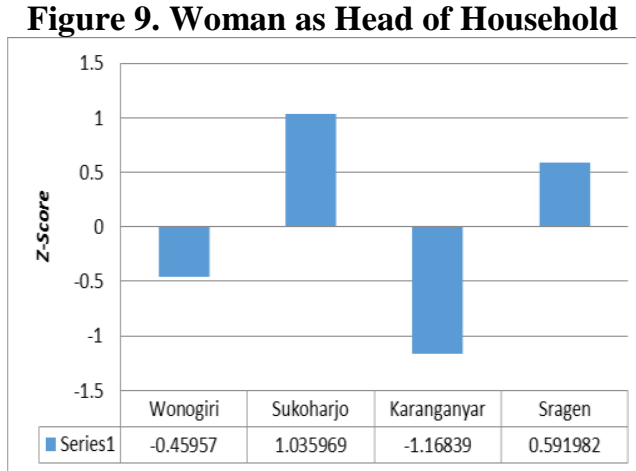

Source: Central Bureau of Statistics
Figure 10. Health Insurance Members

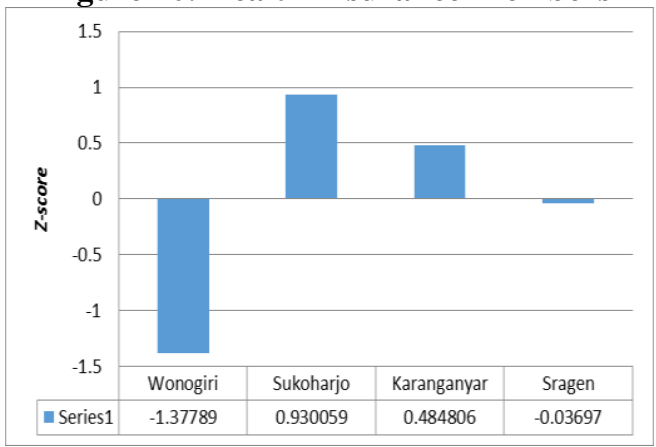

Source: Central Bureau of Statistics

In Figure 1, the highest regional dependence on DAU is Wonogiri Regency with a z-score of 1.328 , Sragen Regency with a z-score of 0 , Sukoharjo Regency with a z-score of -0.242 , and the lowest score is Karanganyar Regency with a z-score of -1.086. Figure 1 explains that the highest socioe-conomic status score is Sragen Regency with a score of 3, Wonogiri Regency and Sukoharjo Regency have the same score, namely 2, and the lowest score is Karanganyar Regency with a score of 1 . The more scores of the components of socioeconomic status obtained indicate the area increasingly vulnerable. One of the sub-components of socio-economic status is dependence on DAU. The greater the General Allocation Fund (DAU) received by a region indicates that the dependence of a region in meeting its needs is still very high. The following is a graph of the dependence of Wonogiri Regency, Sukoharjo Regency, Karanganyar Regency and Sragen Regency on the General Allocation Fund (DAU).

Figure 2 explains that the highest age component is in Wonogiri and Sragen districts with a score of 8, Sukoharjo and Karanganyar regencies also have the same score, namely 7. The more scores you get in the age component, the more SoVI scores are obtained in the area. An area with a larger number of people with an average age means that the area has a greater potential for vulnerability than an area with a small average age. The highest limit for a person's productivity is at the age of 65 years. In figure 2, the more age a person is, the less distance it will be from the age of 65 , which means that someone's chance to be productive is less than the younger one. The district with the highest average age was Wonogiri Regency with a z-score of 1.338 then Sragen Regency with a z-score of 0.125 , followed by Karanganyar Regency with a z-score of -0.482 , and the lowest was Sukoharjo Regency with z- score of -0.981 .

Figure 3 explains the property score shows that the less property score in an area indicates that the area is more vulnerable than other areas. Wonogiri Regency has the highest score among the other 4 districts, namely -6 , Sragen Regency with a score of -7 , Sukoharjo Regency with a score of -8 and Karanganyar Regency with the lowest score, namely -9 . One of the sub-components in property is the number of companies. An area with many operating companies indicates that the area is quite advanced. Furthermore, people who work for companies have a lower vulnerability. This possibility is caused when working in a community company has a fixed salary that can be used to meet their needs. In figure 3, the district with the highest number of companies is Karanganyar Regency with a z-score of 0.907 , then Sukoharjo Regency with a z-score of 0.770508 , Sragen Regency with a $z$-score of -0.54063 , and the number of companies is the least 
located in Wonogiri Regency with a z-score of -1.13661. The less z-score of the number of companies in an area, the less the number of companies in the area, and can increase the social vulnerability score.

Figure 4 explains the regional health component score which has the lowest score is Sragen Regency with a score of -1 , the other three districts namely Wonogiri Regency, Sukoharjo Regency and Karanganyar Regency each have the same score, namely 0 . The greater the score of an area will increase the vulnerability score. social area. One of the sub-components in the health component is the number of people living in nursing homes. The nursing home used in this study is a nursing home that is managed by the government, so that the greater the number of people in the nursing home, it means that the costs borne by the government will increase. In figure 4, when the z-score in an area is getting higher, it will increase the social vulnerability in that area. The highest z-score was in Wonogiri Regency with a score of 1.488, Sragen Regency with a zscore of -0.369 , Sukoharjo Regency with a z-score of -0.452 , and the lowest was Karanganyar Regency with a z-score of -0.666 . The greater the $\mathrm{z}$-score of the number of people living in nursing homes, indicating that the area is more vulnerable than other areas. The highest score for the population component was Karanganyar Regency with a score of 6, Sukoharjo Regency and Sragen Regency with the same score, namely 5, and Wonogiri Regency with the lowest score of 4. The higher the population component score will increase the SoVI score obtained by the region.

In figure 5, the higher the z-score, the higher the SoVI score in that area. The following is a graph of the birth rates from Wonogiri Regency, Sukoharjo Regency, Karanganyar Regency and Sragen Regency. The picture shows that Wonogiri Regency is an area that has the highest zscore, namely 1.49 , Sragen Regency has a z-score of -0.37 , Sukoharjo Regency has a z-score of 0.45 , and the lowest is Karanganyar Regency with z-score of -0.67 . The more basic z-score value of a region's birth rate, the higher the SoVI score of that area. Wonogiri Regency and Sragen Regency have the same gender component score, namely 3, Sukoharjo Regency and Karanganyar Regency both have a score of 2 . The more gender component scores that are owned by an area will increase the SoVI score of the area.

Figure 6, explains that Wonogiri Regency has the highest z-score with a z-score of 1.24. The regency with the second highest z-score was Sragen Regency with a z-score of 0.37, Karanganyar Regency with a z-score of -0.72 , and the lowest was Sukoharjo Regency with a zscore of -0.89. The scores for the rural / urban component of the four districts have the same score, namely 5. In figure 6, the more scores the rural / urban component has in an area, the more it will increase the area's SoVI score. The number of people living in villages and in cities will affect the level of social vulnerability of the community. The more people who live in villages and in cities will both increase their vulnerability.

Figure 7, explains the sub-components that exist in the rural / urban component, one of which is the number of farmers in rural areas. The more people who work as farmers in the village will increase their vulnerability. This is because farmers are jobs that depend on resources, so that when the resources are disturbed, the farmers' lives will also be disturbed. The following is a graph of the number of rural farmers from Wonogiri Regency, Sukoharjo Regency, Karanganyar Regency, and Sragen Regency. In figure 7, the z-score for the sub-component of the number of farmers in rural areas is Wonogiri Regency with a z-score of 1.24, then Sragen Regency with a z- 
score of 0.26 , Karanganyar Regency with a $\mathrm{z}$-score of -0.37 , and the lowest is Sukoharjo Regency with a z-score of -1.12. The z-score value of the sub-component of the number of farmers in rural areas will increase the social vulnerability score in the area. Sragen Regency has the highest score for the work component with a score of 6, Wonogiri Regency has the second highest score with a score of 5, Sukoharjo Regency has a score of 4, and Karanganyar Regency has the lowest score, namely 3. The greater the score of the work component of an area, the higher the total SoVI score for that area.

In Figure 8 it is known that the work sub-component measured is the percentage of people working in the service sector. The service sector is a sector of employment with a low level of vulnerability compared to other sectors. This is because the service sector is not too dependent on existing natural resources. Based on the results of the $\mathrm{Z}$ score analysis, it is known that Sukoharjo Regency has the highest Z-score for the proportion of people working in the service sector with a Z-score of 0.98 , then Karanganyar Regency with a $\mathrm{z}$-score of 0.52 , Sragen Regency with a Zscore of $-0,18$, and the lowest is Wonogiri Regency with a Z-score of -1.32. The higher the Zscore for the percent of people working in the service sector, the lower the social vulnerability score for the area.

Figure 9 shows that the district with the z-score of the number of women who act as head of the family (without husbands) is Sukoharjo Regency with a z-score of 1.04, Sragen Regency with a z-score of 0.59, Wonogiri Regency with a z-score of - 0.46, and the lowest is Karanganyar Regency with a z-score of -1.17. The higher the z-score value for the number of women who act as family heads (without husbands), the higher the SoVI score for that area. Women who have the role of family head will be more vulnerable than families with male family heads. In earning a living, men are usually stronger, especially the head of the family is the responsibility of men, so that men will be more able to be responsible for their families than female heads of families. The following is a graph of the number of women who act as heads of families (without husbands) in Wonogiri Regency, Sukoharjo Regency, Karanganyar Regency and Sragen Regency. One measure of family structure is the number of women who have the role of head of the family. Based on the results of the analysis, it is known that Sragen Regency has a score of 6, Sukoharjo Regency with a score of 5, Wonogiri Regency and Karanganyar Regency both have a score of 4 . The higher the score for the family structure owned by an area, the higher the SoVI score for that area.

Figure 10 describes the conditions of social dependence between districts. Sukoharjo Regency and Karanganyar Regency both have the same social dependency component score, namely 3. Wonogiri Regency and Sragen Regency also have the same score, namely 2. The more scores of the social dependency components obtained, the higher the SoVI score of the area. One of the sub-components in social dependence is the number of BPJS Kesehatan users in the area. The more people who participate in health insurance will increase the dependence of the community on the government. The following is a graph of BPJS Kesehatan users in Wonogiri Regency, Sukoharjo Regency, Karanganyar Regency and Sragen Regency: the highest z-score for BPJS Kesehatan users is Sukoharjo Regency with a z-score of 0.930059, Karanganyar Regency with a z-score of 0.484806. Sragen Regency with a z-score of -0.03697 , and Wonogiri Regency with a z-score of -1.37789. The higher the Z-score value of BPJS Kesehatan users in an area, the higher the SoVI score of that area. 
After obtaining the SoVI score for each regency, in order to classify the regency into different level of vulnerability (low, medium, and high vulnerability), vulnerability classes are made. The calculation for classes' setup is as follow:

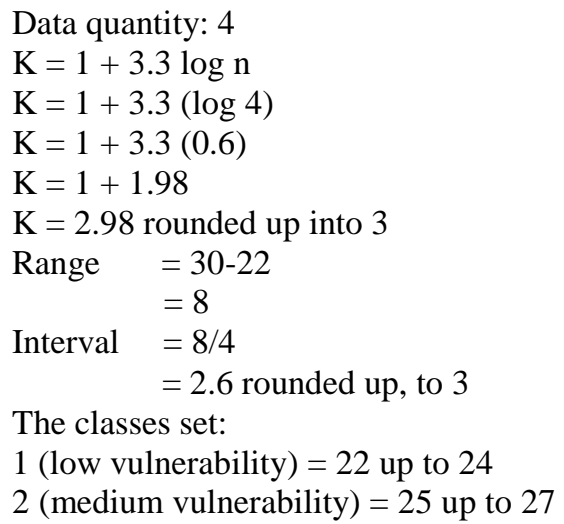

\subsection{Map of Vulnerability using GIS}

This research relied on GIS to illustrate the level of vulnerability of each area. The vulnerability map of Wonogiri, Sukoharjo, Karanganyar, and Sragen Regency is presented in Figure 11. Based on Figure 11, the area depicted with dark red color is the area with higher vulnerability, compared to the area with light color. Figure 1 illustrates that the area with the highest vulnerability level is Sragen Regency. Sukoharjo and Wonogiri Regency are the area with medium vulnerability, while Karanganyar Regency is the area with the lowest vulnerability level. The level of vulnerability is affected by the city/village and occupancy component. This result is in line with the research conducted by Widiarto and Kingma (2014) and Setyaningrum and Giyarsih, 2012), concluded that the floods in Sragen would have been impacted to the farmer households. Further, Setyaningrum and Giyarsih (2012) the vulnerability of the community around Kali Code riverbank is affected by economic sector. 
Figure 11. The Map of Social Vulnerability in the Bengawan Solo Watershed Area

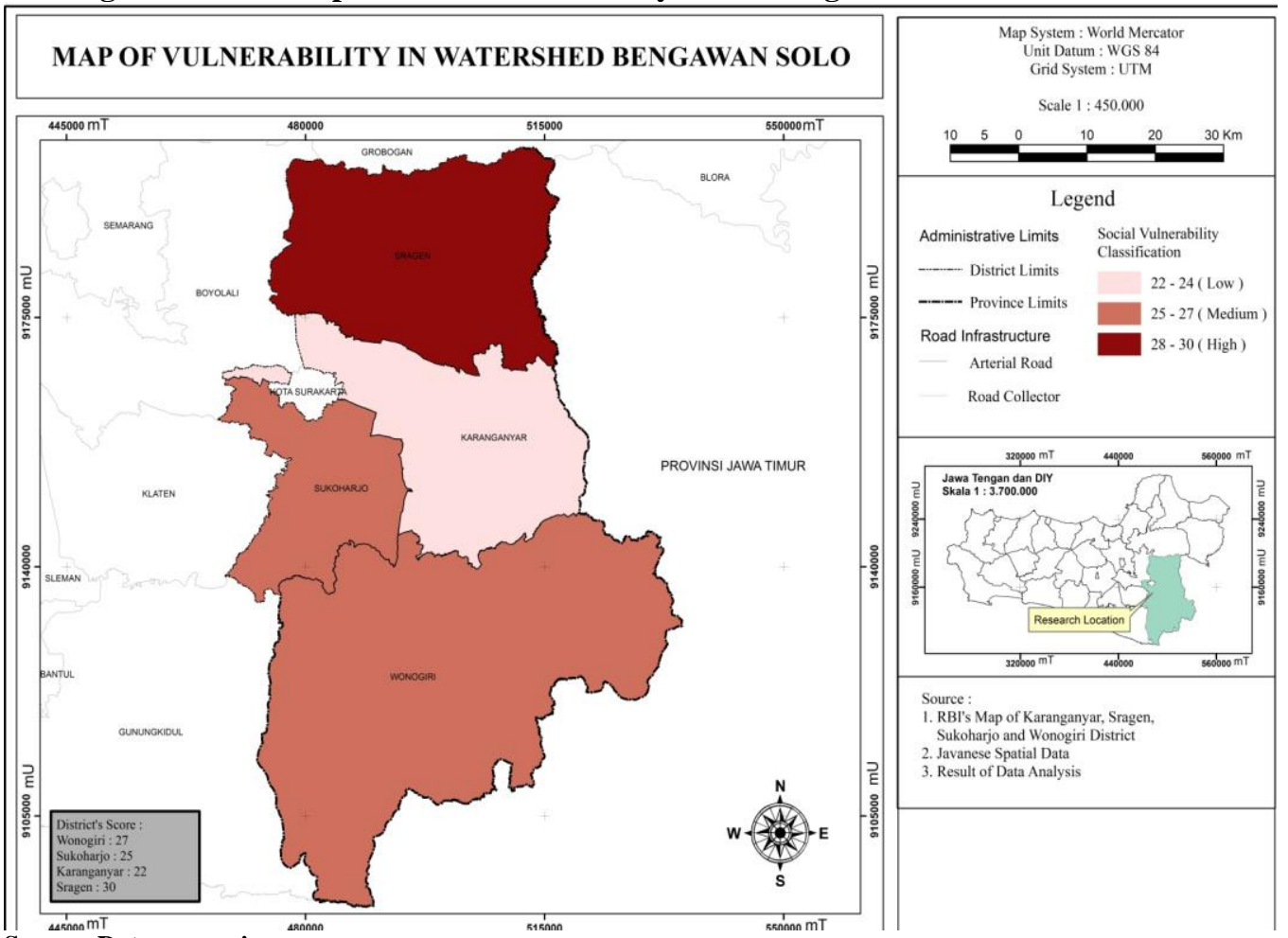

Source: Data processing

\subsection{Socio-Economic Effect}

Natural disasters will actually have an impact on the condition of areas that have high vulnerability to the occurrence of these disasters, this refers to the upstream part of the Bengawan Solo river (Sragen Regency, Sukoharjo Regency, Wonogiri Regency, Karanganyar Regency). The impact of an area's vulnerability to flooding can disrupt economic development and growth, as well as social vulnerability (Widiarto \& Kingma, 2014; Lawal \& Arokoyu, 2015)

Table 3. Socioeconomic Performance Indicator Relates SoVI Score

\begin{tabular}{ccccc}
\hline \hline Regency & \multicolumn{4}{c}{ Sosioeconomic Performance Indicator } \\
& SoVI & P0* $^{*}$ & P2* $^{*}$ & HDI* $^{*}$ \\
\hline Sragen & 30 & 15.48 & 0.63 & 70.34 \\
Sukoharjo & 25 & 9.52 & 0.26 & 73.88 \\
Wonogiri & 27 & 13.66 & 0.51 & 66.84 \\
Karanganyar & 22 & 12.97 & 0.47 & 73.41 \\
\hline \hline
\end{tabular}

Notes: *average index (2010-2018); $\mathrm{P}_{0}$ : Poverty Index (\%); $\mathrm{P}_{2}$ : Poverty Severity Index Source: Central Bureau Statistic, (Data Processed) 
Referring to Rose and Krausmann (2013) there are many aspects that hampered when a disaster occurs, one of which is the socio-economic aspect. An area that often faces natural disasters such as floods usually has a socio-economic effect on people's lives compared to another area that is not affected. Disruption to the socio-economic conditions in an area can increase the vulnerability of the area and a high level of vulnerability will affect poverty. Vulnerability itself is a condition or a consequence of circumstances (physical, social, economic, and environmental) that affects disaster prevention and management efforts (Lawal \& Arokoyu, 2015); (Suryanto \& Rahman, 2019).

Sragen regency which has high vulnerability to disasters has a high percentage of poverty and poverty severity index or expenditure disparity among residents, on the other hand, regions with lower SoVI scores than Sragen regency have lower poverty levels and lower disparities (Table 4). Social and economic vulnerability is the cause and effect of the large loss of flood disasters and the economic level of the community (high percentage of poverty and high poverty severity) makes people in disaster-prone areas have lower economic vulnerability because economically high areas are considered capable of protecting their lives (Hapsoro \& Buchori, 2015).

Disasters (floods) have a tendency to influence cultural factors, livelihoods, and reasoning at the local socio-economic scope. Economic losses due to flooding can be directly observed (for example damaged houses or destroyed business sectors) which have an impact on output losses (unable to produce) and will later create poverty as a result of adjusting the changing structural conditions of society (Enenkel et al., 2015; Kousky et al., 2018).

Table 4: Human Development Index dan Poverty Index in Upper Bengawan Solo Watershed, 2010-2018 (in Percent)

\begin{tabular}{|c|c|c|c|c|c|c|c|c|c|c|}
\hline & Regency & 2010 & 2011 & 2012 & 2013 & 2014 & 2015 & 2016 & 2017 & 2018 \\
\hline \multirow[t]{4}{*}{ HDI } & Sragen & 67.67 & 68.12 & 68.91 & 69.95 & 70.52 & 71.1 & 71.43 & 72.4 & 72.96 \\
\hline & Sukoharjo & 71.53 & 72.34 & 72.81 & 73.22 & 73.76 & 74.53 & 75.06 & 75.56 & 76.07 \\
\hline & Wonogiri & 63.9 & 64.75 & 65.75 & 66.4 & 66.77 & 67.76 & 68.23 & 68.66 & 69.37 \\
\hline & Karanganyar & 70.31 & 71 & 72.26 & 73.33 & 73.89 & 74.26 & 74.9 & 75.22 & 75.54 \\
\hline \multirow[t]{4}{*}{$\mathbf{P}_{0}$} & Sragen & 17.5 & 17.9 & 16.7 & 15.9 & 14.9 & 14.9 & 14.4 & 14 & 13.1 \\
\hline & Sukoharjo & 10.9 & 11.1 & 10.2 & 9.9 & 9.2 & 9.3 & 9.1 & 8.8 & 7.4 \\
\hline & Wonogiri & 15.6 & 15.7 & 14.6 & 14 & 13 & 12.9 & 13.2 & 12.9 & 10.8 \\
\hline & Karanganyar & 13.9 & 15.2 & 14 & 13.5 & 12.6 & 12.4 & 12.4 & 12.2 & 10 \\
\hline
\end{tabular}

Notes: $P_{0}=$ Poverty Index; HDI: Human Development Index

Source: Central Bureau Statistic (Data Processed)

If there is a flood in the upstream area of the Bengawan Solo river, the possibility of economic loss is very high. The economic loss of floods is a trend and extreme projections related to water (floods) that cause economic and life damage, where flood events can be expensive, such as in Central and Eastern Europe in 2013 which caused losses of 15 billion Euros (Jonkman \& Kelman, 2005; Kunreuther \& Michel-kerjan, 2007).

The trend of poverty reduction and increase in HDI (2010-2018) which contradicts the SoVI measurement shows that the index is valid (Table 4). Based on SoVI, Sragen, which has a high level of vulnerability (Table 4), is the area with the highest poverty but in a decreasing trend, as 
well as HDI which continues to increase from year to year. The trend of reducing poverty and increasing HDI also occurs in other upstream areas of the Bengawan Solo river, meaning that there are efforts to prevent and mitigate disasters (floods). The increase in HDI is an indicator in the economic development of the community which continues to improve which also has an impact on reducing poverty, so that people with high economies are able to protect their lives or be able to rise up in the event of a natural disaster.

\section{CONCLUSION}

The Social Vulnerability Index (SoVI) calculation revealed that the area with the highest vulnerability is Sragen Regency followed by Wonogiri and Sukoharjo Regency, and Karanganyar Regency with the lowest vulnerability. Furthermore, the result of socio-economic description based on all the 10 components, Sragen Regency is the most vulnerable area with the highest score on socio-economic status, age, gender, village/city, occupancy, and family structure. Meanwhile, the other three regencies have the relatively the same result in each component.

The result of vulnerability map analysis based on GIS showed that the area with the highest vulnerability is Sragen Regency followed by Wonogiri and Sukoharjo Regency with medium vulnerability, and Karanganyar Regency with the lowest vulnerability. The map also shows that the areas, that geographically adjacent and have a different administration, have a vulnerability level with GIS insigficant difference.

The implication of this study is that local governments can reduce the level of social vulnerability by paying attention to some SoVI indicators. Reducing the level of social vulnerability will directly reduce the risk of increasing poverty, income disparities, and increased government spending. Local governments can allocate budgets to develop strategies to reduce disaster damage by providing provision to communities in vulnerable areas to be more responsive to disasters.

\section{ACKNOWLEDGEMENT}

Thank you for Research and Higher Education Ministry that have been funded this research through Grant Research 2017-2018.

This paper was presented at the ICESD Conference 2020 organized by the Doctoral Program in Environmental Science, Universitas Sebelas Maret.

\section{REFERENCES}

Ali, A., \& Erenstein, O. (2017). Assessing farmer use of climate change adaptation practices and impacts on food security and poverty in Pakistan. Climate Risk Management, 16, 183-194. https://doi.org/10.1016/j.crm.2016.12.001 
Amri, M. R., Yulianti, G., Yunus, R., Wiguna, S., Adi, A. W., Ichwana, A. N., Randongkir, R. E., \& Septian, R. T. (2016). Risiko Bencana Indonesia (Disasters Risk of Indonesia). In R. Jati, \& M. R. Amri (Eds), Direktorat Pengurangan Resiko Bencana Deputi Bidang Pencegahan dan Kesiapansiagaan. BNPB.

Auliyani, D., \& Wahyuningrum, N. (2020). Pola Hujan Di Bagian Hulu Daerah Aliran Sungai Bengawan Solo Dalam Perencanaan Pemanfaatan Sumber Daya Air. JPPDAS, 4(1), 53-62.

Boissiere, M., Locatelli, B., \& Sheil, D. (2013). Local Perceptions of Climate Variability and Change in Tropical Forests of Papua, Local Perceptions of Climate Variability and Change in Tropical Forests of Papua, Indonesia. Ecology and Society, 18(4), 1-15. https://doi.org/10.5751/ES-05822-180413

Enenkel, M., See, L., Bonifacio, R., Boken, V., Chaney, N., Vinck, P., You, L., Dutra, E., \& Anderson, M. (2015). Drought and food security - Improving decision-support via new technologies and innovative collaboration. Global Food Security, 4, 51-55. https://doi.org/10.1016/j.gfs.2014.08.005

Hapsoro, A. H., \& Buchori, I. (2015). Kajian Kerentanan Sosial Dan Ekonomi Terhadap Bencana Banjir (Studi Kasus: Wilayah Pesisir Kota Pekalongan). Jurnal Teknik PWK, 4(4), 542-553.

Hettiarachchi, S., Wasko, C., \& Sharma, A. (2018). Increase in flood risk resulting from climate change in a developed urban watershed - The role of storm temporal patterns. Hydrology and Earth System Sciences, 22(3), 2041-2056. https://doi.org/10.5194/hess-22-2041-2018

Iglesias, A., Quiroga, S., Diz, A., \& Garrote, L. (2011). Adapting agriculture to climate change. Economia Agraria y Recursos Naturales, 11(2), 109-122. https://doi.org/https://doi.org/10.7201/earn.2011.02.05

Jonkman, S. N., \& Kelman, I. (2005). An analysis of the causes and circumstances of flood disaster deaths. Disasters, 29(1), 75-97.

Kifli, F., Mulyo, J., \& Sugiyarto, S. (2015). Analisis Hubungan Kualitas Sumber Daya Manusia Dan Kualitas Sistem Akuntansi Keuangan Daerah Dengan Kualitas Laporan Keuangan Pemerintah Daerah. Prosceeding $2^{\text {nd }}$ University Research Coloquium 2015 (ISSN 24079189).

Kousky, C., Michel-Kerjan, E. O., \& Raschky, P. A. (2018). Does federal disaster assistance crowd out flood insurance? Journal of Environmental Economics and Management, 87, 150-164. https://doi.org/10.1016/j.jeem.2017.05.010

Kunreuther, H. C., \& Michel-kerjan, E. O. (2007). Climate Change, Insurability Of Large-Scale Disasters And The Emerging Liability Challenge (NBER Working Paper No 12821). https://www.nber.org/papers/w12821

Kusenbach, M., Simms, J. L., \& Tobin, G. A. (2010). Disaster Vulnerability and Evacuation Readiness: Coastal Mobile Home Residents in Florida. Natural Hazards, 54(1), 79-95. https://doi.org/10.1007/s11069-009-9358-3

Lawal, O., \& Arokoyu, S. B. (2015). Modelling social vulnerability in sub-Saharan West Africa using a geographical information system. Jàmbá: Journal of Disaster Risk Studies, 7(1), 111. https://doi.org/10.4102/jamba.v7i1.155

Lee, Y. (2014). Social vulnerability indicators as a sustainable planning tool. Environmental Impact Assessment Review, 44, 31-42. https://doi.org/10.1016/j.eiar.2013.08.002

Mcentire, D. (2012). Understanding and reducing vulnerability : from the approach of liabilities and capabilities. Disaster Prevention and Management, 21(2), 206-225. https://doi.org/10.1108/09653561211220007

Miyan, M. A. (2015). Droughts in asian least developed countries: Vulnerability and sustainability. Weather and Climate Extremes, 7, 8-23. 
https://doi.org/10.1016/j.wace.2014.06.003

Opiyo, F., Wasonga, O., Nyangito, M., Schilling, J., \& Munang, R. (2015). Drought Adaptation and Coping Strategies Among the Turkana Pastoralists of Northern Kenya. International Journal of Disaster Risk Science, 6, 295-309. https://doi.org/10.1007/s13753-015-0063-4

Razafindrabe, B. H. N., Parvin, G. A., Surjan, A., Takeuchi, Y., \& Shaw, R. (2009). Climate Disaster Resilience: Focus on Coastal Urban Cities in Asia. Asian Journal of Environment and Disaster Management (AJEDM) - Focusing on Pro-Active Risk Reduction in Asia, 1(1), 101-116. https://doi.org/10.3850/s179392402009000088

Rose, A., \& Krausmann, E. (2013). An economic framework for the development of a resilience index for business recovery. International Journal of Disaster Risk Reduction, 5, 73-83. https://doi.org/10.1016/j.ijdrr.2013.08.003

Runtunuwu, E., \& Syahbuddin, H. (2007). Perubahan Pola Curah Hujan dan Dampaknya Terhadap Periode Masa Tanam. Jurnal Tanah Dan Iklim, 26, 1-12. https://doi.org/http://dx.doi.org/10.2017/jti.v0n26.2007.\%25p

Rusminah, R., \& Gravitiani, E. (2012). Kesediaan Membayar Mitigasi Banjir Dengan Pendekatan Contingent Valuation Method. Jurnal Ekonomi \& Studi Pembangunan, 13(1), 12-23. https://doi.org/10.18196/JESP.13.1.1252

Setyaningrum, P., \& Giyarsih, S. R. (2012). Identifikasi Tingkat Kerentanan Sosial Ekonomi Penduduk Bantaran Sungai Code Yogyakarta terhadap Lahar Merapi. Jurnal Bumi Indonesia, 1(3), 261-269.

Shah, K. U., Dulal, H. B., Johnson, C., \& Baptiste, A. (2013). Understanding livelihood vulnerability to climate change: Applying the livelihood vulnerability index in Trinidad and Tobago. Geoforum, 47, 125-137. https://doi.org/10.1016/j.geoforum.2013.04.004

Shirley, W. L., Cutter, S. L., \& Boruff, B. J. (2003). Social Vulnerability to Environmental Hazards. Social Science Quarterly, 84(2), 242-261.

Surmaini, E., Runtunuwu, E., \& Las, I. (2015). Upaya sektor Pertanian dalam Menghadapi Perubahan Iklim. Upaya Sektor Pertanian Dalam Menghadapi Perubahan Iklim, 30(1), 17. https://doi.org/10.21082/jp3.v30n1.2011.p1-7

Suryanto, S. (2017). Pemetaan Dan Valuasi Ekonomi Kerugian Banjir. PIRAMIDA, XIII(1), 1-8. https://ojs.unud.ac.id/index.php/piramida/article/view/45240

Suryanto, S., \& Rahman, A. (2019). Application of livelihood vulnerability index to assess risks for farmers in the Sukoharjo Regency and Klaten Regency, Indonesia. Jamba: Journal of Disaster Risk Studies, 11(1), 1-9.

Suryanto, Sutrisno, Gravitiani, E., \& Susilowati, F. (2017). Vulnerability and Willingness to Pay for Coping with Flood in Klaten Regency, Central Java, Indonesia. Journal of Business and Economics Review, 2(2), 38-44.

Widiarto, L. A., \& Kingma, N. (2014). Agricultural Loss Caused by 2007 Sidoharjo's Flood and its House-hold Impact. Indonesian Journal of Geography, 46(2), 156-166. https://doi.org/10.22146/ijg.5785 